\title{
Primary Cytomegalovirus Infection and Liver Involvement in Early Infancy
}

\author{
Shunzo Chiba, Shoko Hori, Nagako Kawamura and \\ Tooru Nakao \\ Department of Pediatrics, Sapporo Medical College, Sapporo
}

\begin{abstract}
Chiba, S., Hori, S. Kawamura, N. and Nakao, T. Primary Cytomegalovirus Infection and liver Involvement in early infancy. Tohoku J. exp. Med., 1975, $117(2), 143-151$ - Virus isolation and determination of serum transaminase activity in 237 patients under one year of age were undertaken to clarify the etiologic significance of primary infection with cytomegalovirus (CMV) in infancy. The rates of virus recovery from infants with liver involvement were $37 \%(29 / 78)$ and $42 \%(28 / 66)$, as determined by serum glutamic' oxaloacetic (S-GOT) and serum glutamic pyruvic (S-GPT) transaminase values. In contrast, CMV was recovered from $14 \%(18 / 127)$ and $13 \%(18 / 141)$ of infants with normal S-GOT and S-GPT values. The differences in the rates of virus recovery between both groups were more pronounced in infants under three months of age, that is, 5 to 7 times higher rates in infants with liver involvement. Correlation between complement-fixing antibody and liver involvement, however, was not significant, probably because of the influence by maternal antibody. Majority of infants infected with CMV are postulated to involve liver during immediate months after onset of virus excretion. cytomegalovirus; primary infection
\end{abstract}

Recent studies indicate that vertical transmission in perinatal period is an important epidemiologic factor in primary cytomegalovirus (CMV) infection (Alexander 1967; Diosi et al. 1967; Numazaki et al. 1970; Hayes et al. 1972; Montgomery et al. 1972; Reynolds et al. 1973). In Japan, approximately 60 percent of infants living at home are estimated to be infected with CMV by virus isolation studies (Numazaki et al. 1970). Inspite of such a high prevalence of active infection, the clinical significance in infancy remains obscure. The difficulty seems to be due to low virulence and persistent infection of the virus.

The present study was undertaken to clarify the clinical significance of primary CMV infection in infants. The paper describes the results of virus isolation from infants with various diseases with special reference to liver involvement in early infancy.

\section{Materials and Methods}

\section{Subjects}

Subjects consisted of the patients under one year of age who visited the outpatient clinic or were hospitalized in the Pediatric Clinic of Sapporo Medical College Hospital during 2 years since July 1972. Urine and mouth-swab specimens were obtained from them at

Received for publication, March 11, 1975. 
the first visit or soon after admission to the Hospital for virus isolation. Serum specimens were simultaneously obtained and tested for complement-fixing (CF) antibody to CMV and for glutamic-oxaloacetic (S-GOT) and glutamic-pyruvic (S-GPT) transaminase activities. Liver involvement was estimated as the GOT-value was $50 \mathrm{Karmen}$ units/ml or more and the GPT value $40 \mathrm{Karmen}$ units $/ \mathrm{ml}$ or more.

\section{Tissue cultures}

Human embryonic lung fibroblasts (HEL) prepared in this laboratory were used for virus isolation and preparation of CF antigen. Growth medium consisted of Eagle's minimum essential medium (MEM) supplemented with $10 \%$ fetal bovine serum, and the maintenance medium was MEM with $2 \%$ fetal bovine serum.

\section{Virus isolation}

A $0.2 \mathrm{ml}$ aliquot of fresh urine and mouth-swab specimens, filtrated through 0.4 $\mu$ pore-sized membranes, were inoculated into each of two tubes of HEL. Tubes were observed for the appearance of cytopathic effect (CPE) for 4 weeks before being discarded. CMV was identified by the characteristic CPE and by failure to demonstrate CPE in nonhuman and epithelial cells.

\section{Complement-fixation tests}

The AD-169 strain of CMV received from Dr. Benyesh-Melnick of Baylor College of Medicine was employed for antigen production. The antigen was prepared by glycineextraction of infected HEL (Hallauer and Kronauer 1965), and stored frozen at $-80^{\circ} \mathrm{C}$ until used. CF antibody determinations were performed with the microtechnique (Sever 1962).

\section{REsults}

\section{$C M V$ isolations from infants with various diseases}

Urine and mouth-swab specimens of 237 infants were tested, and CMV was isolated from either of these specimens of 51 infants. The isolation rate was $22 \%$. The age distribution of patients from whom the virus was isolated is shown in Table 1. CMV excreters were first detected at one month of age with the isolation

TABLE 1. Incidence and age distribution of cytomegalovirus isolation in infants with various diseases

\begin{tabular}{cccc}
\hline Age (month) & Number of tested & $\begin{array}{c}\text { Number of } \\
\text { positive }\end{array}$ & $\%$ positive \\
\hline 0 & 19 & 0 & 0 \\
1 & 43 & 4 & 9 \\
2 & 30 & 6 & 20 \\
3 & 42 & 13 & 31 \\
4 & 16 & 4 & 25 \\
5 & 24 & 8 & 33 \\
6 & 12 & 2 & 17 \\
7 & 9 & 2 & 22 \\
8 & 11 & 4 & 36 \\
9 & 7 & 3 & 43 \\
10 & 5 & 1 & 20 \\
11 & 13 & 2 & 15 \\
12 & 6 & 2 & 33 \\
Total & & & 22 \\
\hline
\end{tabular}


rate of $9 \%$. The rate increased and reached to $31 \%$ at 3 months of age, and maintained between 15 and $43 \%$ thereafter. The results of repeated virus isolations from 12 infants are shown in Fig. 1. Virus excretion from urine and/or saliva persisted in almost all the cases through the period of observation.

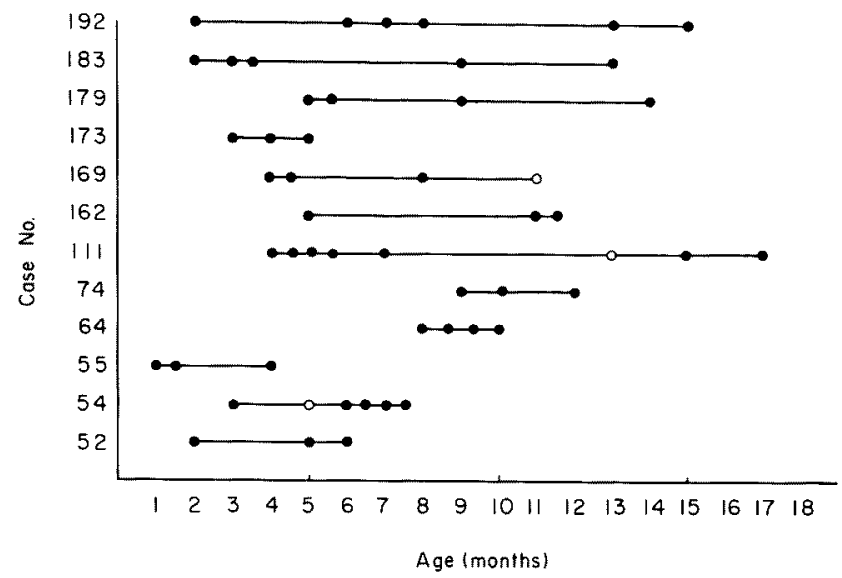

Fig. 1. Results of repeated cytomegalovirus isolation from urine and/or saliva in 12 cases. -, CMV positive; $\circ$, CMV negative.

\section{Disease spectrum of $C M V$ excreters}

Table 2 shows the frequency of CMV isolation in relation to the diseases at the time when virus isolation was carried out. As shown in the table, CMV was isolated from infants with various kinds of diseases and no special relationship was found between CMV and certain disease, though CMV was most frequently recovered from the patients with hepatitis.

\section{Correlation between $C M V$ isolation and liver involvement}

S-GOT and S-GPT tests were carried out simultaneously with virus isolation in 205 and 207 infants, respectively. As shown in Table 3, CMV was isolated at the significantly higher rate from the group of infants with liver involvement than the control group. CMV was isolated from 29 out of $87(37 \%)$ and 28 out of 66 $(42 \%)$ infants with liver involvement determined by the values of S-GOT and SGPT. In contrast, the rates of virus isolation from the infants with normal GOT and GPT values were $14 \%(18 / 127)$ and $13 \%$ (18/141), respectively. The differences in virus isolation rates between normal and abnormal groups were statistically significant $(p<0.05)$, and they were more pronounced in the infants under 3 months of age; 5 to 7 times higher in the infants with liver involvement. Fig. 2 shows the age distribution of CMV excreters by the groups with or without liver involvement. Because of the similarity of the tendency, the results of S-GPT determination group are only shown in the figure. Although the number of older 
TABLE 2. Cytomegalovirus isolation from 232 infants with various diseases

\begin{tabular}{|c|c|c|c|}
\hline Diseases & $\begin{array}{l}\text { Number of } \\
\text { tested }\end{array}$ & $\begin{array}{l}\text { Number of } \\
\text { positive }\end{array}$ & $\%$ positive \\
\hline $\begin{array}{l}\text { Infection } \\
\text { Respiratory tract infection } \\
\text { Alimentary tract infection } \\
\text { Urinary tract infection } \\
\text { Infectious mononucleosis-like } \\
\text { Others }\end{array}$ & $\begin{array}{rr}60 & \\
31 \\
10 \\
\\
\\
\\
\\
4 \\
4 \\
8\end{array}$ & $\begin{array}{l}5 \\
3 \\
1 \\
3 \\
1\end{array}$ & 22 \\
\hline $\begin{array}{l}\text { Liver and bile duct diseases } \\
\text { Hepatitis } \\
\text { Biliary atresia } \\
\text { Hepatomegaly } \\
\text { Prolonged jaundice }\end{array}$ & $\begin{array}{r}54 \\
31 \\
8 \\
4 \\
11\end{array}$ & $\begin{array}{rr}22 & \\
19 \\
1 \\
1 \\
1\end{array}$ & 41 \\
\hline $\begin{array}{l}\text { Neurological diseases } \\
\text { Anomaly } \\
\text { Convulsion } \\
\text { Delayed development } \\
\text { Meningoencephalitis } \\
\text { Others }\end{array}$ & $\begin{array}{rr}56 & \\
& 17 \\
& 18 \\
& 9 \\
& 5 \\
& 7\end{array}$ & $\begin{array}{l}5 \\
5 \\
1 \\
2 \\
1\end{array}$ & 25 \\
\hline Leukemia and other malignancies & 10 & 3 & 30 \\
\hline Congenital heart diseases & 28 & 5 & 18 \\
\hline Skin diseases & 10 & 1 & 10 \\
\hline Muscle diseases & 5 & 1 & 20 \\
\hline Others & 51 & 2 & 4 \\
\hline Total & $274^{*}$ & 61 & 22 \\
\hline
\end{tabular}

* Patients with multiple diseases were indicated in each clinical category

TABLE 3. Correlation between cytomegalovirus isolation and liver involvement in infants with various diseases

\begin{tabular}{lccccccc}
\hline \multirow{2}{*}{ Group } & \multicolumn{3}{c}{ Determined by S-GOT } & & \multicolumn{3}{c}{ Determined by S-GPT } \\
\cline { 2 - 3 } \cline { 7 - 8 } & $\begin{array}{c}\text { Number of } \\
\text { tested }\end{array}$ & $\begin{array}{c}\text { Number of } \\
\text { positive }\end{array}$ & $\%$ positive & $\begin{array}{c}\text { Number of } \\
\text { tested }\end{array}$ & $\begin{array}{c}\text { Number of } \\
\text { positive }\end{array}$ & \% positive \\
\hline $\begin{array}{l}\text { Liver } \\
\text { involvement* }\end{array}$ & 78 & 29 & 37.1 & 66 & 28 & 42.4 \\
Control & 127 & $(18)$ & $(36.0)$ & & $(41)$ & $(17)$ & $(41.4)$ \\
& $(69)$ & 18 & 14.1 & & 141 & 18 & 12.7 \\
Total & 205 & $(5)$ & $(7.2)$ & & $(78)$ & $(5)$ & $(6.4)$ \\
& $(119)$ & $(23)$ & $(19.3)$ & $(119)$ & $(22)$ & $(18.4)$ \\
\hline
\end{tabular}

( ): 0-3 months infant

* Liver involvement was determined as a value of $50 \mathrm{Karmen}$ unit/ml or more S-GOT and 40 Karmen units/ml or more S-GPT.

infants subjected, especially with liver involvement, as too small to evaluate the statistical significance, CMV excreters were much more frequently seen among the younger infants with liver involvement.

Fig. 3 shows the age distribution of infants with liver involvement by virus 

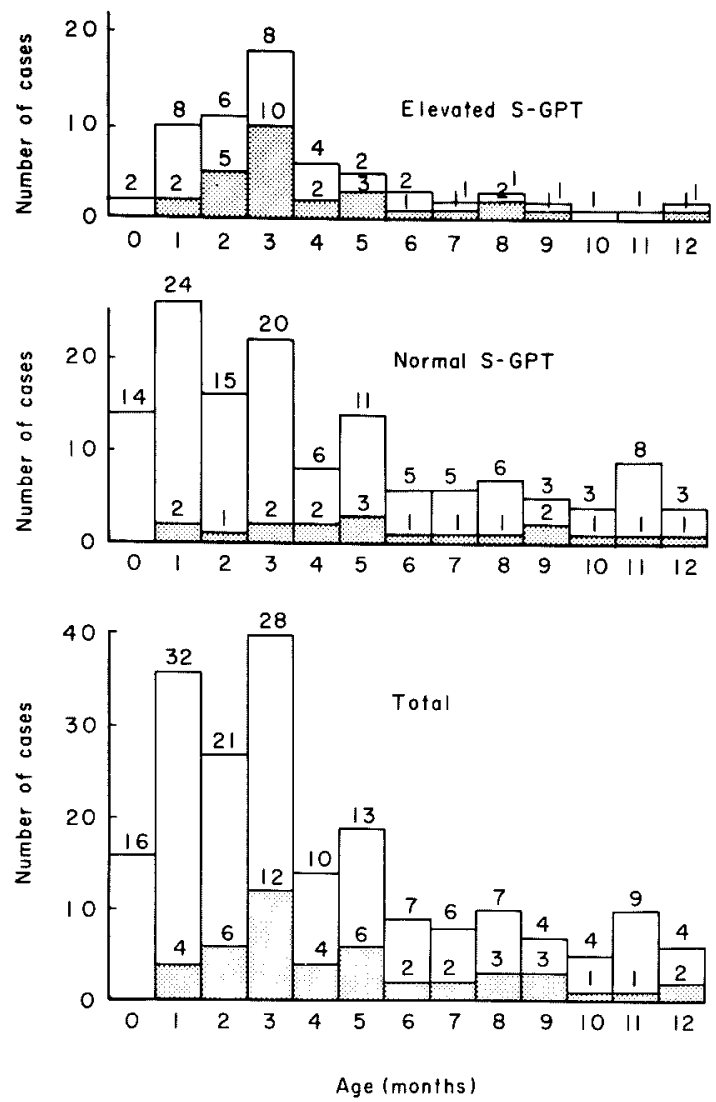

Fig. 2. Age distribution of infants with elevated S-GPT by positive and negative cytomeglaovirus isolation. $\square$, CMV negative; $\sqrt{1.7}$, CMV positive.

positive and negative infants. Elevated values of S-GPT were more frequently observed in the group of CMV excreters, especially in the younger infants.

The relationship between S-GPT values and the rates of virus isolation is shown in Table 4. The values of S-GPT in CMV excreters were distributed from the normal value to 150 units or more. However, CMV was more frequently isolated from infants with higher values of S-GPT.

The results of $C F$ tests in relation to liver involvement

S-GOT and S-GPT tests were carried out on 250 and 244 infants and CF antibody was also determined simultaneously. As shown in Table 4, there was no significant difference between the group of liver involvement and the control group, though CF antibody against CMV was detected slightly more in the infants with liver involvement than the uninvolvement. 

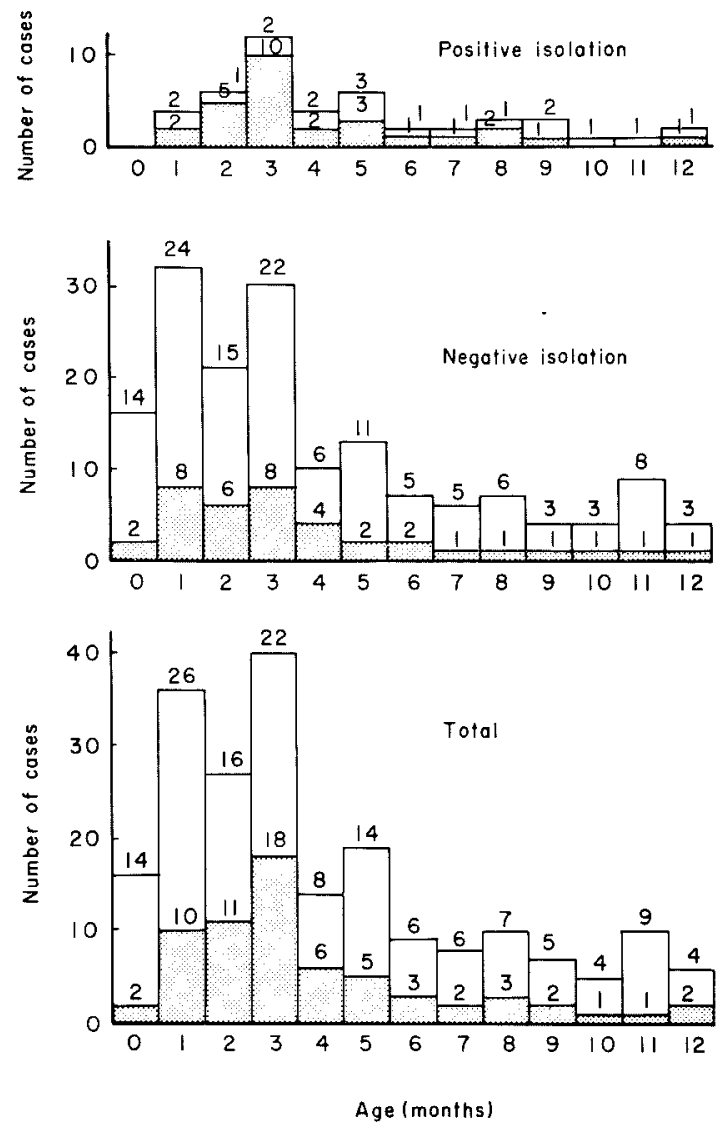

Fig. 3. Age distribution of cytomegalovirus isolations by infants with normal S-GPT values and with elevated. $\square$, normal S-GPT;

TABLE 4. Age distribution of cytomegalovirus isolations in relation to S-GPT values

\begin{tabular}{|c|c|c|c|c|c|c|c|c|c|c|c|c|c|c|}
\hline \multirow{2}{*}{$\begin{array}{c}\text { S-GPT value } \\
(\text { Karmen units } / \mathrm{ml})\end{array}$} & \multicolumn{13}{|c|}{$\begin{array}{c}\text { Number of positive/Number of tested at indicated } \\
\text { months of age }\end{array}$} & \multirow{2}{*}{ Total } \\
\hline & 0 & 1 & 2 & 3 & 4 & 5 & 6 & 7 & 8 & 9 & 10 & 11 & 12 & \\
\hline$<40$ (normal) & $0 / 14$ & $2 / 26$ & $1 / 16$ & $2 / 22$ & $2 / 8$ & $3 / 14$ & $1 / 6$ & $1 / 6$ & $1 / 7$ & $2 / 5$ & $1 / 4$ & $1 / 9$ & $1 / 4$ & $18 / 141$ \\
\hline $40-100$ & $0 / 1$ & $1 / 5$ & $2 / 7$ & $6 / 13$ & $1 / 4$ & $1 / 1$ & $0 / 1$ & $1 / 2$ & $1 / 1$ & $0 / 1$ & $0 / 1$ & $0 / 1$ & $0 / 1$ & $13 / 39$ \\
\hline $100-150$ & $0 / 1$ & $0 / 4$ & $2 / 3$ & $2 / 3$ & $1 / 2$ & $2 / 3$ & $0 / 1$ & $0 / 0$ & $1 / 2$ & $1 / 1$ & $0 / 0$ & $0 / 0$ & $1 / 1$ & $10 / 21$ \\
\hline$>150$ & $0 / 0$ & $1 / 1$ & $1 / 1$ & $2 / 2$ & $0 / 0$ & $0 / 1$ & $1 / 1$ & $0 / 0$ & $0 / 0$ & $0 / 0$ & $0 / 0$ & $0 / 0$ & $0 / 0$ & $5 / 6$ \\
\hline
\end{tabular}

\section{Discussion}

Accumulating evidence indicating perinatal infection through delivery as a common mechanism of viral transmission seems to be important among recent advances in the field of human CMV infection (Alexander 1967: Diosi et al. 1967; Numazaki et al. 1970; Montgomery et al. 1972; Reynolds et al. 1973). Numazaki 
TABLE 5. Correlation between liver involvement and complement-fixing antibody against cytomegalovirus

\begin{tabular}{|c|c|c|c|c|c|c|}
\hline \multirow[b]{2}{*}{ Group } & \multicolumn{3}{|c|}{ Determined by S-GOT } & \multicolumn{3}{|c|}{ Determined by S-GPT } \\
\hline & $\begin{array}{l}\text { Number of } \\
\text { tested }\end{array}$ & $\begin{array}{l}\text { Number of } \\
\text { positive } \\
(\geq 1: 8)\end{array}$ & $\begin{array}{l}\% \text { positive } \\
(\geqq 1: 8)\end{array}$ & $\begin{array}{l}\text { Number of } \\
\text { tested }\end{array}$ & $\begin{array}{c}\text { Number of } \\
\text { positive } \\
(\geqq 1: 8)\end{array}$ & $\begin{array}{c}\% \text { positive } \\
(\geqq 1: 8)\end{array}$ \\
\hline $\begin{array}{l}\text { Liver } \\
\text { involvemont* } \\
\text { Control }\end{array}$ & $\begin{array}{l}79 \\
(47) \\
171 \\
(85)\end{array}$ & $\begin{array}{l}64 \\
(41) \\
118 \\
(62)\end{array}$ & $\begin{array}{c}81.0 \\
(87.2) \\
69.0 \\
(72.9)\end{array}$ & $\begin{array}{l}76 \\
(45) \\
168 \\
(86)\end{array}$ & $\begin{array}{l}60 \\
(39) \\
112 \\
(63)\end{array}$ & $\begin{array}{c}78.9 \\
(86.6) \\
66.6 \\
(73.2)\end{array}$ \\
\hline Total & $\begin{array}{c}250 \\
(132)\end{array}$ & $\begin{array}{c}182 \\
(103)\end{array}$ & $\begin{array}{c}72.8 \\
(78.0)\end{array}$ & $\begin{array}{c}244 \\
(131)\end{array}$ & $\begin{array}{c}172 \\
(102)\end{array}$ & $\begin{array}{c}70.4 \\
(77.8)\end{array}$ \\
\hline
\end{tabular}

* Liver involvement was evaluated as a value of $50 \mathrm{Karmen}$ units/ml or more S-GOT and 40 Karmen units $/ \mathrm{ml}$ or more S-GPT.

( ): 0-3 months infants

and his associates (1970) reported that CMV was recovered, at the rate of $28 \%$, from cervical cultures of pregnant women at the time of delivery and that viral excreters were detected at one month of age and the incidence of excreter increased until five months of age. More recent prospective study by Reynolds et al. (1973) on babies born to mothers whose cervical cultures were positive at late pregnancy indicated that the babies were virus negative at brith and started to excrete virus in urine between three to twelve weeks after birth. Thus recent studies indicate the importance of vertical transmission of CMV in infants living at home, though a greater risk of horizontal infection may be experienced in institutionalized infants (Chiba et al. 1972). Frequencies of CMV recovery from infants in Japan are constant among the studies carried out in the different areas, such as $20 \%$ in Sendai (Numazaki et al. 1970), 23\% in Tokyo (Sakamoto 1974) and 22\% in Sapporo as described above. Age distribution of CMV recovery in the present study also shows a similar pattern to that in Sendai (Numazaki et al. 1970).

Inspite of such a high prevalence of active infection, clinical significance of CMV infection in infancy remains obscure probably because of low virulence and persistent infection of CMV. In many studies in the past, the etiologic significance was discussed in correlation to prevalence rate of CMV isolations and the diseases at the time of collecting specimens. Considering persistency of viral excretion in infancy, however, it is apparently difficult to determine whether CMV is innocent or responsible for various clinical manifestations.

The most important feature of the present study would be in the designation that correlation between virus isolation and liver involvement determined by serum transaminase was studied on the infants within a few months of age when CMV starts to grow rapidly and to be excreted. The results indicate the significant correlation between virus recovery and liver abnormality especially in very early infancy. Correlation between CF antibody and liver involvement was not significant, probably because of the influence by maternal antibody.

Although there are many target organs, various degrees of liver involvement 
seem to be the most common feature of the acquired CMV infection. Hanshaw and his associates (1965) reported significant frequency of liver involvement in asymptomatic children with viruria. Peller and Göetz (1972) also observed a significantly higher frequency of CMV isolations and CF antibodies in children with liver diseases than in age-matched control group. In addition, some investigators reported that the patients with cholestatic or anicteric hepatitis from whom CMV was isolated from urine were frequently associated with a rise of CF antibody against CMV (Toghill et al. 1967; Carter 1968). Furthermore, abnormal liver-function tests are the rule and jaundice is sometimes the presenting sign in "CMV mononucleosis" (Klemola and Kaäriäinen 1965; Lamb and Stern 1965). Such studies, though pathological findings are lacking, strongly suggest a possible causal relationship between CMV and liver disease. The report of the ability of murine CMV to induce hepatitis in mice also supports this possibility (Henson et al. 1966).

Regarding to hepatitis or liver disease in infants, there have been some reports indicating the etiologic significance of CMV infection. Weller and Hanshaw (1962) recovered CMV from 4 out of 10 specimens of liver tissue with histologic changes suggestive of neonatal hepatitis. Cytomegalic cells were demonstrated in 2 of the 4 virologically positive specimens. Stulberg et al. (1966) could also recover CMV from liver biopsy material or blood specimen of 2 patients with neonatal hepatitis. On the other hand, Medearis (1964) reported the failure of CMV recovery from 21 infants with liver diseases of unknown etiology. Thus the etiologic significance of CMV in liver disease in infants has been controversial. Since the discovery of $\mathrm{HB}-\mathrm{Ag}$ as a marker of hepatitis B virus infection, neonatal hepatitis has been the subject of extensive study. The authors also examined for HB-Ag in the sera of the infants diagnosed as hepatitis, but failed to detect HB$\mathrm{Ag}$ in any of them. The preliminary data were described previously (Chiba et al. 1974).

Finally, on the basis of the results obtained in the present study, the authors wish to figure out the clinical significance of primary CMV infection in infants as follows: Infected infants, most probably from mothers during perinatal period, start to excrete CMV in urine or saliva after one to three months of incubation period. The immediate months after incubation period are critical for evaluation of any overt evidence of viral replication in target organs other than urinary tract and salivary gland. During this period, majority of infected infants pass symptomatic or asymptomatic liver involvement in reflection of viral growth in the liver. After recovery from liver damage, the infants continue to excrete CMV for many months, reflecting continuous infection confined to salivary gland and urinary tract. Accordingly, in later infancy CMV excreters show wider spectrum of diseases, and the relationship between CMV and certain diseases becomes difficult to be specified. Supposing that a syndrome called "CMV-mononucleosis" is a typical manifestation of primary CMV infection in adults and elder children, it should be postulated that liver involvement is the only manifestation of primary infection with CMV in younger infants, if present. 


\section{References}

1) Alexander, E.R. (1967) Maternal and neonatal infection with cytomegalovirus in Taiwan. Pediat. Res., 1, 210-210.

2) Carter, A.R. (1968) Cytomegalovirus disease presenting as hepatitis. Brit. med. $J$,, 3, 786-786.

3) Chiba, S., Fujiwara, T., Shiono, H. \& Nakao, T. (1973) Frequency of Australia antigen detected by redioimmunoassay in hepatitis in children. Tohoku J. exp. Med., 109, 307-308.

4) Chiba, S., Ikeda, S., Chiba, Y., Agatsuma, Y., Ohsaki, M. \& Nakao, T. (1972) Epidimic of subclinical infection with cytomegalovirus in an infant home. Tohoku $J$. exp. Med., 106, 387-389.

5) Diosi, P., Babusceac, L., Nevinglovschi, O. \& Kun-Stoici, G. (1967) Cytomegalovirus infection associated with pregnancy. Lancet, 2, 1063-1066.

6) Hallauer, C. \& Kronauer, G. (1965) Extraction of cell-associated virus without damage. Arch. ges. Virusforsch., 15, 433-440.

7) Hanshaw, J.B., Betts, R.F., Simon, G. \& Boyton, R.C. (1965) Acquired cytomegalovirus infection. Association with hepatosplenomegaly and abnormal liver-function tests. New Engl. J. Med., 272, 602-609.

8) Hayes, K., Danks, D.M., Gibas, H. \& Jack, I. (1972) Cytomegalovirus in human milk. New Engl. J. Med., 287, 177-178.

9) Henson, D., Smith, R.D. \& Gehrke, J. (1966) Non-fatal mouse cytomegalovirus hepatitis. Amer. J. Path., 49, 871-888.

10) Klemola, E. \& Kääriäinen, L. (1965) Cytomegalovirus as a possible cause of a disease resembling infectious mononucleosis. Brit. med. J., 2, 1099-1102.

11) Lamb, S.G. \& Stern, H. (1966) Cytomegalovirus mononucleosis with jaundice as presenting sign. Lancet, 2, 1033-1006

12) Medearis, D.N., Jr. (1964) Observations concerning human cytomegalovirus infection and disease. Bull. Johns Hopkins Hosp., 114, 181-211.

13) Montgomery, R., Youngblood, L. \& Medearis, D.N., Jr. (1972) Recovery of cytomegalovirus from the cervix in pregnancy. Pediatrics, 49, 524-531.

14) Numazaki, Y., Yano, N., Morizuka, T., Takai, S. \& Ishida, N. (1970) Primary infection with human cytomegalovirus; Virus isolation from healthy infants and pregnant women. Amer. J. Epid., 91, 410-417.

15) Peller, P. \& Göetz, O. (1972) Die Bedeutung des Zytomegalievirus für die Lebererkrankungen im Kindesalter. Dtsh. med. Wschr., 97, 321-323.

16) Reynolds, D.W., Stagno, S., Hosty, T.S., Tiller, M. \& Alford, C.A., Jr. (1973) Maternal cytomegalovirus excretion and perinatal infection. New Engl.J. Med., 289, $1-5$.

17) Sakamoto, H. (1974) A Study on cytomegalovirus infection in children. Acta Paed. Japon., 16, 15-17.

18) Sever, J.L. (1962) Application of a microtechnique to viral serological investigation. J. Immunol., 88, 320-329.

19) Stulberg, C.S., Zuelzer, W.W., Page, P.H., Taylor, P.E. \& Brough, A.J. (1966) Cytomegalovirus infections with reference to isolations from lymph nodes and blood. Proc. Soc. exp. Biol. Med., 123, 976-982.

20) Toghill, P.J., Bailey, M.E., Williams, R., Zeeger, R. \& Bown, R. (1967) Cytomegalovirus hepatitis in the adult. Lancet, 1, 1351-1354.

21) Weller, T.H. \& Hanshaw, J.B. (1962) Virologic and clinical observations on cytomegalic inclusion disease. New Engl. J. Med., 266, 1233-1244. 